\title{
Viljellyn kirjolohen rehutehoa voi parantaa valintajalostuksella
}

\author{
Antti Kause ${ }^{1)}$, Declan Tobin ${ }^{2)}$, Dominic Houlihan ${ }^{2)}$, Sam Martin ${ }^{2)}$, Esa A. Mäntysaari ${ }^{1)}$, Ossi Ritola ${ }^{3)}$, ja \\ Kari Ruohonen ${ }^{4)}$ \\ ${ }^{1)}$ MTT Maa- ja elintarviketaloudentutkimuskeskus,Eläinjalostus, 31600 Jokioinen, antti.kause@mtt.fi \\ ${ }^{2)}$ School of Biological Sciences, Department of Zoology, University of Aberdeen, Aberdeen, AB24 2TZ, UK \\ ${ }^{3)}$ Riista- ja kalatalouden tutkimuslaitos,Tervon kalantutkimus ja vesiviljely, 72210 Tervo \\ ${ }^{4)}$ Riista- ja kalatalouden tutkimuslaitos, Turun riistan- ja kalantutkimus, 20520 Turku
}

Kotieläinten rehutehon parantaminen vähentää ympäristöpäästöjä ja lisää taloudellista tuottavuutta. Viljeltyjen kalojen yksilöllistä rehutehon genetiikkaa ei ole aikaisemmin tutkittu. Tutkimme kuinka suuria geneettisiä muutoksia kirjolohen rehutehossa (päiväkasvu/päivärehunkulutus) on saavutettavissa valintajalostuksen avulla. Tutkimme 1) voidaanko rehutehoa parantaa valitsemalla pelkästään nopeaa kasvua, ja 2) kuinka paljon rehuteho paranee jos valitaan samanaikaisesti nopeaa kasvua ja vähäistä rehunkulutusta. Lisäksi tutkimme 3) vaikuttaako rehunkoostumus kasvun ja rehunkulutuksen vaihteluun ja niiden väliseen suhteeseen ja siten saavutettaviin geneettisiin vasteisiin.

Heritabiliteettien ja korrelaatioiden laskemiseksi kasvu ja rehunkulutus mitattiin 2931 kalasta, joiden sukupuu oli tiedossa. Kaloja kasvatettiin kahdella rehulla, normaalirehulla (proteiinipitoisuus 40\%, rasvapitoisuus $30 \%$ ) ja korkeaproteiinisella rehulla (proteiinipitoisuus 50\%, rasvapitoisuus $20 \%$ ). Normaalirehu vastaa modernia käytössä olevaa rehua. Hypoteesina oli, että normaalirehulla nopeasti kasvavat kalat syövät paljon ja varastoivat paljon rasvaa. Korkeaproteiinisen rehun proteiinipitoisuus ylittää kalojen proteiinitarpeen. Tällöin kalat, joilla on heikko proteiininkäyttökyky kasvavat huonosti ja joutuvat varastoimaan ylimääräisen proteiinin rasvana. Näin korkeaproteiinisella rehulla nopea kasvu ei ole voimakkaasti yhteydessä rasvan varastoitumiseen eikä korkeaan rehunkulutukseen.

Rehunkulutuksen heritabiliteetti oli 0.11 , joten rehunkulutuksessa on geneettistä vaihtelua, joka on hyödynnettävissä valinnan avulla. Päiväkasvun heritabiliteetti oli 0.41 . Kuten oletettiin, normaalirehulla kasvu ja rehunkulutus olivat tiukasti geneettisesti korreloituneita $\left(r_{\mathrm{A}}=0.91\right)$, joten on vaikeaa parantaa rehutehoa valitsemalla samanaikaisesti nopeaa kasvua ja vähäistä rehunkulutusta. Hypoteesin mukaisesti korkeaproteiinisella rehulla kasvun ja rehunkulutuksen välinen geneettinen korrelaatio oli matalampi $\left(r_{\mathrm{A}}=0.53\right)$, joten rehutehokkuuden parantaminen on helpompaa.

Rehutehossa saavutettavat geneettiset muutokset ennustettiin valintaindeksi-teorian avulla. Molemmilla rehuilla pelkkä nopean kasvun valinta johtaa rehutehon paranemiseen. Korkeaproteiinisella rehulla nopean kasvun ja vähäisen rehunkulutuksen samanaikainen valinta parantaa rehutehoa 1.2 kertaa enemmän kuin pelkkä nopean kasvun valinta. Normaalirehulla vähäisen rehunkulutuksen valinta ei juurikaan paranna rehutehoa, koska kasvun ja rehunkulutuksen välinen geneettinen korrelaatio on niin voimakas.

Tulokset osoittavat, että viljellyn kirjolohen rehutehoa voi parantaa valintajalostuksella. Nykyisessä valintaohjelmassa tämä tehdään valitsemalla nopeaa kasvua, joka parantaa myös rehutehoa. Valinnalla saavutettavat kasvun, rehunkulutuksen ja rehutehon geneettiset muutokset riippuvat kuitenkin ravitsemusympäristöstä.

Avainsanat: eläinjalostus, kirjolohi, rehuteho, valinta. 


\section{Johdanto}

Tässä tutkimuksessa selvitimme kuinka suuria geneettisiä muutoksia kirjolohen rehutehossa (kasvu/rehunkulutus) on saavutettavissa valintajalostuksen avulla. Kotieläinten rehutehon parantaminen on tärkeää, koska se vähentää ympäristöpäästöjä ja lisää taloudellista tuottavuutta. Viljeltyjen kalojen yksilöllisen rehutehon ja rehunkulutuksen genetiikkaa ei kuitenkaan ole aikaisemmin tutkittu, eikä rehutehoa tai rehunkulutusta nykyisissä kalojen valintaohjelmissa suoraan jalosteta. Tämä johtuu siitä, että yksilöllistä rehunkulutusta on ollut vaikea mitata suuresta määrästä kaloja. Tässä tutkimuksessa kirjolohen yksilöllinen rehunkulutus mitattiin käyttämällä rehussa röntgenkuvassa näkyvää merkkiainetta. Näin saimme estimoitua kasvun ja rehunkulutuksen geneettiset parametrit (heritabiliteetit ja geneettiset korrelaatiot), ja ennustimme kuinka suuria geneettisiä vasteita erilaiset valintastrategiat tuottavat rehutehossa.

Rehutehoa voidaan parantaa valitsemalla nopeaa kasvua ja vähäistä rehunkulutusta. Näin kala kasvaisi nopeammin, mutta söisi vähemmän. Nykyisissä kalojen valintaohjelmissa valitaan nopeaa kasvua, mutta rehunkulutusta ei edes mitata. Koska rehunkulutuksen mittaaminen on työlästä, onkin mielekästä kysyä kuinka paljon kirjolohen rehuteho paranee kun valitaan pelkkää kasvua. On odotettavissa, että kalojen kasvun valitseminen parantaa rehutehoa, koska näin on todettu tapahtuvan kotieläimilläkin. Toisaalta on mielekästä tutkia, kuinka paljon rehutehon parantaminen tehostuu jos rehunkulutusta mitataan ja valitaan. Näitä eri valintastrategioita vertaamalla voidaan tutkia rehunkulutuksen mittaamisen ja valinnan hyötyjä.

Rehunkoostumus voi vaikuttaa kasvun ja rehunkulutuksen vaihteluun ja ominaisuuksien välisiin korrelaatioihin. Tässä tutkimuksessa kaloja kasvatettiin kahdella eri rehulla: normaalilla rehulla (proteiinipitoisuus $40 \%$, rasvapitoisuus $30 \%$ ) ja korkeaproteiinisella rehulla (proteiinipitoisuus $50 \%$, rasvapitoisuus $20 \%$ ). Normaalirehu vastaa modernia käytössä olevaa rehua. Hypoteesina oli, että normaalirehulla nopeasti kasvavat kalat syövät paljon ja varastoivat paljon rasvaa. Korkeaproteiinisen rehun proteiinipitoisuus ylittää kalojen proteiinitarpeen. Tällöin kalat, joilla on heikko proteiininkäyttökyky kasvavat huonosti ja joutuvat varastoimaan ylimääräisen proteiinin rasvana. Näin korkeaproteiinisella rehulla nopea kasvu ei ole voimakkaasti yhteydessä rasvan varastoitumiseen ja korkeaan rehunkulutukseen. Hypoteesina oli siis, että normaalirehulla kasvu ja rehunkulutus ovat voimakkaammin korreloituneita kuin korkeaproteiinisella rehulla.

Tässä tutkimuksessa selvitimme:

1) päivittäisen kasvun ja rehunkulutuksen heritabiliteetit ja korrelaatiot,

2) voidaanko rehutehoa parantaa valitsemalla pelkästään nopeaa kasvua,

3) kuinka paljon rehuteho paranee jos valitaan samanaikaisesti nopeaa kasvua ja vähäistä rehunkulutusta, ja

4) vaikuttaako ravitsemusympäristö kasvun ja rehunkulutuksen vaihteluun ja niiden väliseen suhteeseen, ja siten valinnalla saavutettaviin geneettisiin vasteisiin.

\section{Aineisto ja menetelmät}

\section{Kalamateriaali ja rehukäsittelyt}

Tämä tutkimus on osa EU-rahoitteista hanketta 'Protein and Growth Efficiency in Salmonid Selection (PROGRESS)', Q5RS-2001-0994, jonka koordinaattorina toimii Kari Ruohonen. Tutkimuksessa käytettiin kaloja Suomen kansallisesta kirjolohen JALO-valintaohjelmasta, jota RKTL ylläpitää yhdessä MTT:n kanssa Tervon kasvatuslaitoksella (Kause et al. 2005). Hedelmöityksissä tehtiin 210 perhettä käyttäen 89 isää ja 109 emää. Näistä perheistä yksilömerkittiin 2931 kalaa ensimmäisen kasvukauden jälkeen keskipainon ollessa noin $62 \mathrm{~g}$.

Merkinnän jälkeen kukin perhe jaettiin kahteen osaan, jotka ruokittiin eri rehukäsittelyillä. Käytetyt rehut olivat modernia rehua vastaava normaalirehu (proteiinipitoisuus $40 \%$, rasvapitoisuus $30 \%$ ) ja kokeellinen korkeaproteiininen rehu (proteiinipitoisuus 50\%, rasvapitoisuus 20\%). Kummastakin rehukäsittelystä oli neljä toistotankkia, joihin kukin perhe jaettiin tasaisesti.

Rehukäsittelyt vaikuttivat merkitsevästi ennen kaikkea kalojen ruhonkoostumukseen, mutta myös rehunkulutukseen. Normaalirehulla, jonka rasvapitoisuus on korkeampi, ruhon rasvapitoisuus oli merkitsevästi korkeampi (Tobin et al., lähetetty). Tämä tulos oli kirjallisuuden perusteella odotettavissakin. Toisaalta rehunkulutus oli merkitsevästi korkeampaa korkeaproteiinisella rehulla (Kause 
et al. 2006). Rehukäsittelyt siis vaikuttivat kaloihin, ja koeasetelma oli sopiva tutkimaan miten ravitsemusympäristö vaikuttaa kasvun ja rehunkulutuksen geneettisiin parametreihin.

\section{Ominaisuuksien mittaus}

Kalojen päiväkasvu (g/vrk) ja päivittäinen rehunkulutus (g/vrk) mitattiin markkinakokoisesta kalasta toisen (aika 1, keskipaino 750g) ja kolmannen kasvukauden jälkeen (aika 2, keskipaino 2000g). Kumpanakin ajankohtana päivittäinen kasvu ja rehunkulutus mitattiin kolmena päivänä kolme viikkoa kestäneen testiajan aikana. Toistomittaukset ovat tarpeen, koska rehunkulutuksen toistettavuus on alhainen $(r=0.09-0.32)$. Kunkin kalan kolmesta toistomittauksesta laskettiin yksilölle keskiarvo, joita käytettiin analyysissä. Analysoitavat ominaisuudet olivat $\mathrm{kasvu}_{1}, \mathrm{kasvu}_{2}$, rehunkulutus $\mathrm{j}_{1}$ a rehunkulutus 2 .

Rehunkulutus mitattiin kalojen röntgenkuvista. Testipäivänä kaloille syötettiin rehua, jossa oli röntgenkuvassa näkyviä pieniä lasikuulia. Ruokinnan jälkeen kalat nukutettiin ja röntgenkuvattiin. Kunkin kalan vatsalaukussa olleet lasikuulat laskettiin röntgenkuvasta ja näin saatiin estimoitua syöty rehumäärä (Talbot ja Higgins 1983).

\section{Geneettiset parametrit}

Päivittäisen kasvun ja rehunkulutuksen geneettiset parametrit estimoitiin DMU-ohjelmistolla, joka hyödyntää REML (restricted maximum likelihood) metodia. Ohjelmistolla laskettiin ominaisuuksien heritabiliteetit $\left(h^{2}=\right.$ geneettinen varianssi/fenotyyppinen varianssi) sekä fenotyyppiset ja geneettiset korrelaatiot.Käytetty tilastollinen malli oli:

$\mathrm{y}_{\mathrm{ijk}}=\operatorname{anim}_{\mathrm{i}}+\operatorname{SEXMAT}_{\mathrm{j}}+$ TESTTANK$_{\mathrm{k}}+\varepsilon_{\mathrm{ijk}}$,

jossa $y_{i j k}$ on yksilön i havainto, ja kiinteinä tekijöinä ovat sukupuoli ja sukukypsyysikä $\left(\operatorname{SEXMAT}_{\mathrm{j}}\right)$ ja toistotankki (TESTTANK $\mathrm{k}_{\mathrm{k}}$ ), ja satunnaistekijöinä yksilön additiivinen geneettinen vaikutus $\left(\mathrm{anim}_{\mathrm{i}}\right) \mathrm{ja}$ jäännösvaihtelu $\left(\varepsilon_{\mathrm{ijk}}\right)$. Eri rehuilla mitatut ominaisuudet käsiteltiin eri ominaisuuksina.

\section{Ennustetut geneettiset muutokset}

Massavalinnalla saavutettavat geneettiset muutokset kasvussa, rehunkulutuksessa ja rehutehossa ennustettiin Hazelin (1943) valintaindeksi-teorian avulla kummallekin rehulle erikseen.

Ensin rakennettiin kummallekin rehulle kasvun ja rehunkulutuksen fenotyyppiset ja geneettiset varianssi-kovarianssi-matriisit. Tässä yhteydessä oletettiin, että keskiarvo kahdella rehulla mitatusta heritabiliteetista kuvaa molempien rehujen geneettistä vaihtelua (kts. tulokset). Sen sijaan kummallekin rehulle käytettiin sen omaa fenotyyppistä varianssia, ja geneettisiä ja fenotyyppisiä korrelaatioita. Käytetyt varianssi-kovarianssi-matriisit olivat kahden mittausajankohdan keskiarvo.

Tämän jälkeen erilaisia valintastrategioita vertailtiin valintaindeksi-teorian avulla. Koska ominaisuuksien varianssi-kovarianssi-matriisit ovat tiedossa, voidaan laskea kuinka suuria geneettisiä muutoksia ominaisuuksissa tapahtuu kun tiettyä valintastrategiaa noudatetaan. Ensimmäisessä valintastrategiassa oletettiin, että valinta kohdistuu ainoastaan kasvuun, jolloin valintaindeksissä taloudellinen paino on kokonaan kasvulla. Näin voidaan testata kuinka paljon rehunkulutus ja rehuteho muuttuvat korreloituneina geneettisinä vasteina, kun valitaan ainoastaan kasvua. Toisessa valintastrategiassa valintaindeksin painoa siirrettiin rehunkulutukselle, niin että valitaan yht'aikaisesti nopeaa kasvua ja alhaista rehunkulutusta. Näin voidaan tutkia pystytäänko rehutehoa parantamaan jos rehunkulutus on valintaindeksissä mukana. Valintaintensiteetin oletettiin olevan 0.50 .

Rehutehossa saavutettava geneettinen muutos lasketiin käyttäen sen komponenteissa - kasvussa ja rehunkulutuksessa - tapahtuvia muutoksia. Ensin rehutehon arvo (päiväkasvu/päivärehunkulutus) laskettiin ennen valintaa. Tämän jälkeen kasvulle ja kulutukselle ennustettiin valintastrategiasta seuraavat geneettiset muutokset yhden sukupolven jälkeen, ja uusi valinnan jälkeinen rehutehon arvo laskettiin. Näin vältetään tilastotieteellisesti hankalan osuutena määriteltävän rehutehon suora analyysi. 


\section{Tulokset ja tulosten tarkastelu}

\section{Kasvun ja rehunkulutuksen vaihtelu}

Tulokset osoittivat, että rehukäsittelyt muuttivat ominaisuuksien fenotyyppistä vaihtelua. Päiväkasvun fenotyyppinen vaihtelukerroin $\left(C V_{p}\right)$ oli korkeampi normaaliproteiinisella rehulla (Taulukko 1). On luultavaa, että normaalirehun korkea rasvapitoisuus ja siitä seuraava nopea kasvu edesauttavat hitaasti ja nopeasti kasvavien kalojen erottumista toisistaan. Sen sijaan rehunkulutuksen fenotyyppinen vaihtelukerroin oli korkeampi korkeaproteiinisella rehulla. On mahdollista, että tehokkaasti ja tehottomasti proteiinia käyttävät kalat reagoivat erilailla uuteen korkeaproteiiniseen rehuun lisäten rehunkulutuksen vaihtelua.

Kasvun ja rehunkulutuksen heritabiliteeteissä ei ollut suuria eroja rehujen välillä (Taulukko 1). Rehunkulutuksen keskimääräinen heritabiliteetti oli 0.11 , joten rehunkulutuksessa on geneettistä vaihtelua, joka on hyödynnettävissä valinnan avulla. Päiväkasvun heritabiliteetti oli 0.41 , joka on hieman korkeampi kuin kalojen painolle estimoitu heritabiliteetti (Kause et al. 2005).

Taulukko 1. Päivittäisen kasvun ja rehunkulutuksen fenotyyppinen varianssi $\left(\sigma_{\mathrm{P}}^{2}\right)$, vaihtelukerroin $\left(C V_{\mathrm{P}}\right)$, heritabiliteetti $\left(h^{2}\right)$ ja sen keskivirhe (SE) kahdella rehulla.

\begin{tabular}{|c|c|c|c|c|c|c|c|c|}
\hline & \multicolumn{4}{|c|}{ Normaali proteiini } & \multicolumn{4}{|c|}{ Korkea proteiini } \\
\hline & $\sigma_{\mathrm{P}}^{2}$ & $C V_{\mathrm{p}}$ & $h^{2}$ & SE & $\sigma_{\mathrm{P}}^{2}$ & $C V_{\mathrm{p}}$ & $h^{2}$ & SE \\
\hline $\mathrm{Kasvu}_{1}(\mathrm{~g} / \mathrm{vrk})$ & 6.19 & 66.3 & 0.49 & 0.11 & 3.52 & 55.3 & 0.40 & 0.10 \\
\hline $\mathrm{Kasvu}_{2}$ (g/vrk) & 38.6 & 36.2 & 0.42 & 0.12 & 29.3 & 35.2 & 0.33 & 0.10 \\
\hline Rehunkulutus $_{1}$ (g/vrk) & 2.08 & 44.5 & 0.17 & 0.10 & 5.07 & 59.3 & 0.06 & 0.07 \\
\hline Rehunkulutus $_{2}(\mathrm{~g} / \mathrm{vrk})$ & 33.5 & 41.1 & 0.02 & 0.07 & 112 & 58.5 & 0.19 & 0.11 \\
\hline
\end{tabular}

\section{Kasvun ja rehunkulutuksen yhteys}

Hypoteesin mukaisesti kasvun ja rehunkulutuksen välinen korrelaatio oli voimakkaampi normaaliproteiinisella rehulla (Taulukko 2). Normaalirehulla kasvu ja rehunkulutus olivat tiukasti fenotyyppisesti $\left(r_{\mathrm{P}}=0.54\right)$ ja geneettisesti korreloituneita $\left(r_{\mathrm{A}}=0.91\right)$, joten on vaikeaa parantaa rehutehoa valitsemalla samanaikaisesti nopeaa kasvua ja vähäistä rehunkulutusta. Hypoteesin mukaisesti korkeaproteiinisella rehulla kasvun ja rehunkulutuksen välinen fenotyyppinen $\left(r_{\mathrm{P}}=0.31\right)$ ja geneettinen korrelaatio $\left(r_{\mathrm{A}}=0.52\right)$ oli matalampi, joten rehutehon parantaminen on helpompaa. Nämä tulokset ovat yhtenevät rasvan kertymisen kanssa. Kuten oletettiin, nopeasti kasvavat kalat varastoivat paljon rasvaa normaalirehulla, mutta eivät korkeaproteiinisella rehulla (Tobin et al., lähetetty).

Taulukko 2. Päivittäisen kasvun ja rehunkulutuksen välinen fenotyyppinen $\left(r_{\mathrm{P}}\right)$ ja geneettinen korrelaatio $\left(r_{\mathrm{A}} \pm \mathrm{SE}\right)$ kahdella rehulla ja kahtena mittausajankohtana.

\begin{tabular}{lccccc}
\hline Mittausajankohta & \multicolumn{2}{c}{ Normaali proteiini } & & \multicolumn{2}{c}{ Korkea proteiini } \\
\cline { 2 - 3 } \cline { 5 - 6 } & $r_{\mathrm{P}}$ & $r_{\mathrm{A}} \pm \mathrm{SE}$ & & $r_{\mathrm{P}}$ & $r_{\mathrm{A}} \pm \mathrm{SE}$ \\
\hline Aika 1 & 0.56 & $0.86 \pm 0.11$ & & 0.34 & $0.76 \pm 0.34$ \\
Aika 2 & 0.51 & $0.96 \pm 0.57$ & & 0.27 & $0.28 \pm 0.29$ \\
\hline
\end{tabular}

\section{Kasvun valitseminen parantaa rehutehoa}

Molemmilla rehuilla pelkkä nopean kasvun valinta johtaa rehutehon paranemiseen, eikä rehutehossa saavutettavissa muutoksissa ollut suurta eroa rehujen välillä. Valintaindeksi-teoriaan perustuvat laskelmat osoittivat, että pelkästään kasvua valittaessa kasvu paranee normaalirehulla 9.3\% ja korkeaproteiinisella rehulla $8.8 \%$. Tämä geneettinen muutos on lähes samansuuruinen kun kirjolohen valintaohjelmassa on todellisuudessa saavutettu (Kause et al. 2005). Kasvua valittaessa rehunkulutus nousee 4.7\% (normaalirehu) ja 3.9\% (korkeaproteiininen rehu) korreloituneena geneettisenä vasteena. Koska rehunkulutus nousee vähemmän kuin kasvu, parantuu rehuteho automaattisesti. Siksi pelkästään kasvua valittaessa rehuteho nousee normaalirehulla $4.2 \%$ ja korkeaproteiinisella rehulla $4.6 \%$. Rehutehon paraneminen on siis noin kaksi kertaa hitaampaa kuin kasvun.

Koska rehunkulutuksen mittaaminen röntgen-tekniikalla on epätarkkaa, on mahdollista että tässä 
kokeessa estimoitu rehunkulutuksen heritabiliteetti on matalampi kuin todellisuudessa. Olettamalla, että rehunkulutuksen heritabiliteetti olisikin 0.25 , saadaan esimerkiksi pelkästään kasvua valittaessa kulutukselle jopa 5.8\% nousu korkeaproteiinisella rehulla. Näin rehutehossa tapahtuva paraneminen putoaa $2.7 \%$ :iin. Toisin sanoen rehutehon geneettinen edistyminen on noin kolme kertaa hitaampaa kun kasvussa tapahtuva edistyminen.

Näistä tuloksista voidaan tehdä kaksi johtopäätöstä. Rehutehoa voidaan parantaa valitsemalla nopeaa kasvua, koska nopea kasvu on geneettisesti yhteydessä hyvään rehutehoon. Toiseksi, kun kasvua valitaan on rehutehossa tapahtuva nousu noin 2-3 kertaa pienempi kuin kasvun nousu.

\section{Rehunkulutuksen valitsemisen edut}

Kun kasvua ja rehunkulutusta valitaan yhtäaikaa, ravitsemusympäristö vaikuttaa valinnalla saavutettaviin geneettisiin vasteisiin. Normaalirehulla nopean kasvun ja vähäisen rehunkulutuksen valinta ei juurikaan paranna rehutehoa, koska kasvun ja rehunkulutuksen välinen geneettinen korrelaatio on niin voimakas. Kun valintaindeksissä taloudellinen paino kasvulle on $75 \%$ ja rehunkulutusta vastaan $-25 \%$, on rehutehossa tapahtuva geneettinen edistyminen maksimissaan. Tällöin rehuteho on $4.3 \%$ korkeampi kuin valintaa ennen (pelkän kasvun valinnalla 4.2\%). Lisähyöty on siis marginaalinen.

Korkeaproteiinisella rehulla nopean kasvun (75\%) ja vähäisen rehunkulutuksen $(-25 \%)$ samanaikainen valinta parantaa rehutehoa 1.2 kertaa enemmän kuin pelkkä nopean kasvun valinta. Rehutehossa tapahtuva geneettinen muutos on $5.7 \%$ (pelkän kasvun valinnalla $4.6 \%$ ). Tämä johtuu korkeaproteiinisen rehun matalammasta kasvun ja rehunkulutuksen välisestä korrelaatiosta, joka mahdollistaa molempien ominaisuuksien samanaikaisen jalostamisen. Näin rehunkulutuksen valinnalla saavutettu hyöty on korkeampi kuin normaalirehulla.

Tuloksista voidaan päätellä, että nykyrehuilla rehunkulutuksen mittaaminen ja valitseminen röntgen-menetelmällä ei tuota toivotun kaltaista etua parantuneena rehutehona. Koska rehunkulutuksen mittaaminen on työlästä ja siitä saavutettavat hyödyt eivät ole suuria, on päätetty, että rehutehoa parannetaan kirjolohen valintaohjelmassa nopeaa kasvua valitsemalla.

\section{Johtopäätökset}

Viljellyn kirjolohen rehutehoa voi parantaa valintajalostuksella. Nykyisessä valintaohjelmassa tämä tehdään valitsemalla nopeaa kasvua, joka parantaa myös rehutehoa. Kasvussa, rehunkulutuksessa ja rehutehossa saavutettavat geneettiset muutokset voivat kuitenkin riippua ravitsemusympäristöstä.

\section{Kirjallisuus}

Hazel, L. N. 1943. The genetic basis of constructing selection indices. Genetics 28: 476-490.

Kause, A., Ritola, O., Paananen, T., Wahlroos, H., \& Mäntysaari, E.A. 2005. Genetic trends in growth, sexual maturity and skeletal deformations, and rate of inbreeding in a breeding programme for rainbow trout. Aquaculture 247: 177-187.

Kause, A., Tobin, D., Houlihan, D.F., Martin, S.A.M., Mäntysaari, E.A., Ritola, O. \& Ruohonen, K. 2006. Feed efficiency of rainbow trout can be improved through selection: Different genetic potential on alternative diets. J. Anim. Sci., painossa.

Talbot, C. \& Higgins, P.J. 1983. A radiographic method for feeding studies on fish using metallic iron powder as marker. J. Fish Biol. 23: 211-220. 